\title{
REVIEW
}

\section{A systematic review of the evidence supporting a role for vasopressor support in acute SCI}

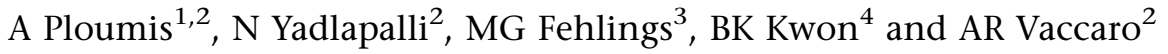 \\ ${ }^{1}$ Division of Orthopaedics and Rehabilitation, Department of Surgery, University of Ioannina, Ioannina, Greece; \\ ${ }^{2}$ Department of Orthopaedics, Thomas Jefferson University, Philadelphia, PA, USA; ${ }^{3}$ Division of Neurosurgery and Spinal Program, \\ Department of Surgery, University of Toronto, Toronto, Ontario, Canada and ${ }^{4}$ Department of Orthopaedics, University of British \\ Columbia, Vancouver, British Columbia, Canada
}

\begin{abstract}
Study design: A systematic review of clinical and preclinical literature.
Objective: To critically evaluate the evidence supporting a role for vasopressor support in the management of acute spinal cord injury and to provide updated recommendations regarding the appropriate clinical application of this therapeutic modality.

Background: Only few clinical studies exist examining the role of arterial pressure and vasopressors in the context of spinal cord trauma.

Methods: Medical literature was searched from the earlier available date to July 2009 and 32 articles (animal and human literature) answering the following four questions were studied: what patient groups benefit from vasopressor support, which is the optimal hypertensive drug regimen, which is the optimal duration of the treatment and which is the optimal arterial blood pressure. Outcome measures used were the incidence of patients needing vasopressors, the increase of arterial blood pressure and neurologic improvement.

Results: Patients with complete cervical cord injuries required vasopressors more frequently than either incomplete injuries or thoracic/lumbar cord injuries $(P<0.001)$. There was no statististical difference in neurologic improvement between patients on vasopressor support with a mean arterial pressure (MAP) of less than $85 \mathrm{~mm} \mathrm{Hg}$ and those with MAP less than $90 \mathrm{~mm} \mathrm{Hg}$. Duration of treatment is often recommended between 5 and 7 days although this is not supported by high-level evidence and no single vasopressor appeared superior over the variety used in clinical treatment.

Conclusion: There is currently no gold standard on vasopressor support. Based on non-randomized human studies, complete cervical cord injuries require vasopressors more frequently than other spinal cord injuries.
\end{abstract}

Spinal Cord (2010) 48, 356-362; doi:10.1038/sc.2009.150; published online 24 November 2009

Keywords: hypotension; vasopressor; spinal cord injury; mean arterial pressure

\section{Introduction}

The incidence of cardiovascular abnormalities following acute spinal cord injuries (ASCIs) is very common, particularly after cervical injuries. ${ }^{1-3}$ Many patients exhibit hypotension and bradycardia due a sudden loss of sympathetic outflow and relative hypovolemia. This combination, referred to as 'neurogenic shock', is common in patients with acute cervical tetraplegia or high thoracic paraplegia. With impaired spinal cord autoregulation, this neurogenic shock can contribute to hypoperfusion of the spinal cord and further ischemic insult. In a study conducted by Lehmann

Correspondence: Assistant Professor A Ploumis, Division of Orthopaedics and Rehabilitation, Department of Surgery, University of Ioannina, University Campus, loannina 45100, Greece.

E-mail: aploumis@cc.uoi.gr

Received 3 August 2009; revised 6 October 2009; accepted 13 October 2009; published online 24 November 2009 et al. ${ }^{1} 100 \%$ of the patients that had a severe cervical injury suffered from persistent bradycardia and $68 \%$ of the patients suffered from hypotension.

Given the paucity of effective interventions for acute human SCI, it is important that all possible clinical measures be taken to minimize secondary damage and potentially improve neurologic outcome. In traumatic brain injury, restoring normal blood pressure has proven to be beneficial for neurologic recovery, and aggressive vasopressor support with fastidious monitoring of systemic and intracranial pressure is standard of care for these patients in most neurotrauma institutions. ${ }^{4}$ Comparatively less is known about traumatic spinal cord injury (SCI), however. In two studies, aggressively providing hemodynamic support to maintain adequate perfusion and blood pressure was shown to improve the mortality rates and neurological outcome of patients with ASCI. ${ }^{5,6}$ 
Guidelines have recently been published by the Spinal Cord Medicine Consortium that provide direction for clinicians in their hemodynamic management of patients with ASCI. ${ }^{7}$ Here, we performed a systematic review of the literature on the topic of hemodynamic support for ASCI, with the goals of characterizing the clinical phenomenon of neurogenic shock, evaluating appropriate vasopressor agents, determining the optimal duration of treatment and identifying the hemodynamic parameters that warrant commencement of vasopressors.

\section{Materials and methods}

An electronic English literature search was conducted using the MEDLINE (1950 to April 2008) and EMBASE databases (1974 to July 2009). The search strategy included the following terms: acute spinal cord injury, hypotension, hypertension therapy, vasopressors, cardiovascular abnormalities, spinal shock and neurogenic shock. In addition, the Cochrane Central Register of Clinical Trials and the Cochrane Database of Systematic Reviews were searched in the updated registry of the first quarter of the year 2009. Additional sources included conference proceedings and systematic reviews published from January 2005 to April 2008. Both animal and human studies were included. Full text articles were found for abstracts that referred to treatment options and clinical outcomes for arterial pressure changes following ASCI. The references from these articles were also searched for relevant articles. The first two authors (AP and NY) reviewed the articles and reached a consensus opinion.

The articles were narrowed down to those that answered four questions:

1. What patient groups (complete or incomplete SCI, cervical or thoracic level of injury) incur a neurologic benefit from having aggressive hemodynamic support?

2. What is the most effective vasopressor regimen?

3. What is the optimal duration of treatment?

4. What is the optimal mean arterial pressure (MAP) to sustain adequate spinal cord perfusion?

These articles were rated according to their level of evidence. $^{8}$

Outcome measures in patients with SCIs included the incidence of instituting vasopressor support, the percentage of neurologic improvement and increase in blood pressure.

For comparisons, vasopressor support outcomes were grouped under separate categories (that is, complete vs incomplete injuries, cervical vs thoracic/lumbar injuries, criterion $\mathrm{MAP}<85$ vs $<90 \mathrm{~mm} \mathrm{Hg}$ ). Mantel-Haenszel method $\left(\chi^{2}\right.$-test) was used to combine results and analyze with a fixed effects model. Meta-analyses on these limited data set were performed using Review Manager ${ }^{5}$ (The Cochrane Collaboration, Copenhagen, 2008). ${ }^{9}$

\section{Results}

Our search showed 374 articles relevant to vasopressor support in patients with ASCI. Most of the studies were review papers but there were 25 papers of experimental clinical studies and 7 human clinical studies. All of the clinical studies were either level III or level IV studies without a control group for comparison.

Experimental studies of hypertensive therapy in animals with SCI Following experimental spinal cord trauma immediate hypotension occurs (acute phase) followed by hypertension at a later stage (chronic phase). This reaction simulates neurogenic shock and autonomic hyperreflexia in humans. ${ }^{10,11}$ Nine studies specifically tested the use of various pharmacologic agents for hemodynamic support in animals with SCIs (Table 1). Mean blood pressure and more specifically, spinal cord blood flow increased significantly using a combination of nimodipine (calcium channel blocker) with epinephrine (vasopressor), dextran (colloid), phenylephrine (vasopressor) and mildly with epinephrine and whole blood.

Guha et al. ${ }^{12}$ found that extreme hypertension induced by epinephrine after SCI did not significantly increase spinal cord blood flow.

What patient groups need vasopressor support (complete or incomplete SCI, cervical, thoracic or lumbar level of injury) according to their neurologic improvement?

Levi et al. ${ }^{5}$ reported that patients with complete motor deficits are 5.5 times more likely to have a systolic blood pressure (SBP) less than $90 \mathrm{~mm} \mathrm{Hg}$ at admission than patients with motor function. Tuli et al. ${ }^{13}$ reported that at admission the SBP is significantly higher for AIS C and D compared with AIS B. Regarding the severity of paralysis (complete vs incomplete), four studies were found comparing the institution and effect of vasopressors in the setting of complete and incomplete spinal cord lesions (Table 2). Patients with complete SCI more frequently needed vasopressor support $(P<0.01)$.

A complete cervical cord injury leads to loss of central supraspinal sympathetic control and, therefore, more pronounced hypotension. ${ }^{14}$ Patients with severe cervical cord injuries are more prone to hemodynamic and cardiac abnormalities within the first 1-2 weeks after injury. ${ }^{1,2}$ Lehmann et al. ${ }^{1}$ found hypotension in $68 \%$ of the studied patients with SCI with complete cervical cord injury and no hypotension in either incomplete cervical or thoracolumbar cord injuries. In a retrospective study of patients with SCIs receiving appropriate medical and surgical treatment, motor complete patients initially showed a neurologic motor recovery rate of up to $15 \%$ whereas motor incomplete patients showed a motor recovery rate of $80 \%$ on average. ${ }^{15}$

As to the level of paralysis (cervical vs thoracic), only four studies (including Lehmann et al.) evaluated the institution of vasopressor support based on level of injury. Patients with cervical cord injuries required vasopressor support more frequently than patients with thoracolumbar injuries $(P<0.001$; Table 3$)$.

This review confirms that the need for vasopressors is more pronounced in cervical cord injuries with complete neurologic deficit. This does not mean that vasopressors are 
Table 1 Experimental studies accessing hypertensive therapy in animal models of spinal cord injuries

\begin{tabular}{|c|c|c|c|c|c|}
\hline Study & Species & Medication & Effect on MAP & Effect on spinal cord effusion & Effect on functional recovery \\
\hline $\begin{array}{l}\text { Guha, Tator and } \\
\text { Rochon }^{12}\end{array}$ & Rats & Epinephrine & $\begin{array}{l}\text { Increase both in mild } \\
\text { and severe injury }\end{array}$ & $\begin{array}{l}\text { Increase only in mild } \\
\text { injury and not in severe }\end{array}$ & \\
\hline Wallace and Tator ${ }^{33}$ & Rats & $\begin{array}{l}\text { Albumin or autologous } \\
\text { packed cells or low } \\
\text { molecular dextran or } \\
\text { autologous whole blood }\end{array}$ & $\begin{array}{l}\text { Increase only with } \\
\text { dextran and whole } \\
\text { blood }\end{array}$ & $\begin{array}{l}\text { Dextran } 200 \% \text { increase } \\
\text { and whole blood } 100 \% \\
\text { increase }\end{array}$ & \\
\hline Wallace and Tator ${ }^{34}$ & Rats & Naloxone & No beneficial effect & No beneficial effect & \\
\hline Dolan and Tator ${ }^{35}$ & Rats & Norepinephrine & Increase only MAP & & No effect \\
\hline $\begin{array}{l}\text { Guha, Tator, Smith } \\
\text { and Piper }\end{array}$ & Rats & $\begin{array}{l}\text { Epinephrine vs } \\
\text { nimodipine plus } \\
\text { epinephrine }\end{array}$ & $\begin{array}{l}\text { Both nimodipine- } \\
\text { epinephrine and } \\
\text { epinephrine alone } \\
\text { increased MAP }\end{array}$ & $\begin{array}{l}\text { Nimodipine and } \\
\text { epinephrine increased } \\
\text { profoundly, whereas } \\
\text { epinephrine alone no } \\
\text { significant increase }\end{array}$ & \\
\hline Gambardella et al. ${ }^{37}$ & Rabbits & $\begin{array}{l}\text { Saline vs epinephrine } \\
\text { vs nimodipine vs } \\
\text { epinephrine plus } \\
\text { nimodipine }\end{array}$ & & & $\begin{array}{l}\text { Combination of epinephrine } \\
\text { plus nimodipine led to } \\
\text { greatest increase, second } \\
\text { best epinephrine }\end{array}$ \\
\hline Ross and Tator ${ }^{38}$ & Rat & Nimodipine & $\begin{array}{l}\text { No significant increase } \\
\text { even in the highest } \\
\text { dose of nimodipine }\end{array}$ & & $\begin{array}{l}\text { No recovery at any dose of } \\
\text { nimodipine }\end{array}$ \\
\hline Dyste et $a .^{39}$ & Lamb & $\begin{array}{l}\text { Hetarstach vs mannitol } \\
\text { vs phenylephrine }\end{array}$ & $\begin{array}{l}\text { Increase both in those } \\
\text { received Hetarstach or } \\
\text { phenylephrine }\end{array}$ & $\begin{array}{l}\text { Increase only in those } \\
\text { received phenylephrine }\end{array}$ & \\
\hline Fehlings et al. ${ }^{21}$ & Rat & $\begin{array}{l}\text { Nimodipine vs dextran } \\
\text { vs saline vs combinations }\end{array}$ & $\begin{array}{l}\text { Increase only in those } \\
\text { received combination } \\
\text { of nimodipine-dextran }\end{array}$ & $\begin{array}{l}\text { Increase only in those } \\
\text { received combination } \\
\text { of nimodipine-dextran }\end{array}$ & $\begin{array}{l}\text { Improvement only in those } \\
\text { received combination of } \\
\text { nimodipine-dextran }\end{array}$ \\
\hline
\end{tabular}

Abbreviation: MAP, mean arterial pressure.

Table 2 Effect of severity of injury on need for vasopressor support

\begin{tabular}{|c|c|c|c|c|c|}
\hline Author & $\begin{array}{l}\text { Criterion for initiating } \\
\text { vasopressors }\end{array}$ & $\begin{array}{l}\text { No. of patients and } \\
\text { neurologic status }\end{array}$ & $\begin{array}{l}\text { Patients needing } \\
\text { vasopressor therapy }\end{array}$ & $\begin{array}{l}\text { Follow-up } \\
\text { length }\end{array}$ & $\begin{array}{c}\text { No. of patients } w / \text { neurological } \\
\text { improvement (\% of total) }\end{array}$ \\
\hline \multirow[t]{2}{*}{ Vale et $a l^{6}$} & \multirow[t]{2}{*}{$\mathrm{MAP}<85 \mathrm{~mm} \mathrm{Hg}$} & 31 Complete & 16 & \multirow[t]{2}{*}{12 months } & $13(42)$ \\
\hline & & 33 Incomplete & 15 & & $24(72)$ \\
\hline \multirow[t]{2}{*}{ Levi et al..$^{5}$} & \multirow[t]{2}{*}{$\mathrm{MAP}<90 \mathrm{~mm} \mathrm{Hg}$} & 31 Complete & 31 & \multirow[t]{2}{*}{6 weeks } & $10(32)$ \\
\hline & & 19 Incomplete & 10 & & $10(53)$ \\
\hline \multirow[t]{2}{*}{ Levi et al. ${ }^{40}$} & \multirow[t]{2}{*}{$\mathrm{MAP}<85 \mathrm{~mm} \mathrm{Hg}$} & 53 Complete & Not specified & \multirow[t]{2}{*}{12 months } & $23(43)$ \\
\hline & & 50 Incomplete & Not specified & & $24(48)$ \\
\hline \multirow[t]{2}{*}{ Wolf et al. ${ }^{30}$} & \multirow[t]{2}{*}{$\mathrm{MAP}<85 \mathrm{~mm} \mathrm{Hg}$} & 34 Complete & Not specified & \multirow[t]{2}{*}{12 months } & $7(20.6)$ \\
\hline & & 13 Incomplete & Not specified & & $8(61.6)$ \\
\hline
\end{tabular}

Abbreviation: MAP, mean arterial pressure.

Table 3 Effect of level of injury on need for vasopressor support

\begin{tabular}{|c|c|c|c|}
\hline Author & Criterion for initiating vasopressors & No. of patients & $\begin{array}{l}\text { Patients needing vasopressor } \\
\text { support according to level of injury }\end{array}$ \\
\hline Vale et $a l^{6}$ & $\mathrm{MAP}<85 \mathrm{~mm} \mathrm{Hg}$ & $\begin{array}{l}29 \text { Cervical } \\
35 \text { Thoracic }\end{array}$ & $\begin{array}{r}22 \\
9\end{array}$ \\
\hline Lehmann et al. ${ }^{1}$ & $\mathrm{SBP}<90 \mathrm{~mm} \mathrm{Hg}$ & $\begin{array}{l}48 \text { Cervical } \\
23 \text { Thoracolumbar }\end{array}$ & $\begin{array}{r}11 \\
0\end{array}$ \\
\hline Billelo et al. ${ }^{41}$ & $\mathrm{SBP}<90 \mathrm{~mm} \mathrm{Hg}$ & $\begin{array}{l}62 \text { Upper cervical (C1-5) } \\
21 \text { Lower cervical (C6-7) }\end{array}$ & $\begin{array}{r}15 \\
1\end{array}$ \\
\hline Levi et al. ${ }^{5}$ & $\mathrm{MAP}<90 \mathrm{~mm} \mathrm{Hg}$ & 50 Cervical & 41 \\
\hline
\end{tabular}

Abbreviations: MAP, mean arterial pressure; SBP, systolic blood pressure.

unnecessary in cases of incomplete injuries or thoracic/ lumbar cord injuries, but rather, that hypotension is less commonly experienced in these settings.
What is the best hypertensive drug regimen depending on its actions? In a study by Levi et al. ${ }^{5}$ on 50 patients with cervical ASCI, dobutamine $\left(5-15 \mu \mathrm{g} \mathrm{kg}^{-1}\right.$ per $\left.\mathrm{min}\right)$ and/or dopamine 
(2-10 $\mu \mathrm{g} \mathrm{kg}^{-1}$ per min) were used along with fluids to control patient's hemodynamic profile. Dobutamine was used primarily as it improved cardiac contractility more effectively than dopamine. Vale et al., ${ }^{6}$ in a study of 77 patients with ASCI, treated patients with an MAP less than $85 \mathrm{~mm} \mathrm{Hg}$ with dopamine $\left(2.5-5 \mu \mathrm{g} \mathrm{kg}^{-1}\right.$ per min) followed by norepinephrine (0.01-0.2 $\mu \mathrm{g} \mathrm{kg}^{-1}$ per min) if necessary.

Five studies using different vasopressor agents were reviewed (Table 4). All of them were successful in improving blood pressure above the targeted critical value. Owing to the heterogeneity of the studies, no statistical analysis could be performed to determine which, if any, of the vasopressor agents are better.

What is the optimal duration of treatment?

There were four studies reporting the optimal duration of vasopressor support (Table 5). Treatment ranged from 5 to 7 days on average. Most of the reported findings were not specific for their effect on the cardiovascular system or neurologic recovery. Therefore, optimal treatment duration could not be determined.

What is the MAP below which one should commence vasopressor support?

Four studies (Table 2) evaluated neurologic improvement following pressure support initiation for MAP $<85$ or $<90$ as criterion for initiating therapy. There was no significant difference $(P>0.05)$ in terms of neurologic improvement between the initiation of pressures for an MAP $<85$ or $<90$ as a criterion for initiating therapy.

\section{Discussion}

Hypotension in acute spinal cord injured patients leads to decreased cord perfusion and the potential for further secondary ischemic cord injury. ${ }^{16}$ Before initiating any vasopressor agent, proper fluid replacement is required to enhance the action of the vasopressors. ${ }^{17}$ The target pulmonary capillary wedge pressure is approximately $18 \mathrm{~mm} \mathrm{Hg}$ with a systolic arterial pressure between 80 and $100 \mathrm{~mm} \mathrm{Hg} .{ }^{18,19}$ Volume resuscitation is undertaken first by crystalloids and then by colloids (that is, dextran, fresh frozen plasma or red blood cell units when hemoglobin is low). Other causes of hemodynamic instability (that is, bleeding, tension pneumothorax, myocardial infraction, cardiac tamponade, sepsis) should be excluded before attributing hemodynamic instability to neurogenic shock. Spinal cord blood flow has been shown to be adversely affected following traumatic SCI and an increase in blood pressure leads to significant improvement in axonal function both in the motor and somatosensory tracts of the cord. ${ }^{20,21}$

The sympathetic supply to the heart originates in T1-T4 cord level. Injuries at or above this level lead to decreased myocardial contractility and heart rate. In addition, irrespective of the level of cord injury, supraspinal sympathetic drive to the peripheral vessels is interrupted, and the pooling of blood within the peripheral circulation leads to hypotension. $^{22}$ In Table 6 , the most widely used vasopressors are listed. Vasopressors that are $\alpha$-receptor agonists result in peripheral vasoconstriction and elevation of blood pressure. $\beta$-Receptors agonists are responsible for increased cardiac contractility and heart rate. According to the recommendations by the Consortium for Spinal Cord Medicine, ${ }^{7}$ cervical and upper thoracic cord injuries down to T6 warrant a

Table 4 Effectiveness of vasopressor support in increasing blood pressure in patients with $\mathrm{SCl}$

\begin{tabular}{|c|c|c|c|c|c|}
\hline Study & $\begin{array}{l}\text { No of } \\
\text { patients }\end{array}$ & Level of injury & Vasoactive agents & $\begin{array}{l}\text { Criterion for start } \\
\text { of vasopressors } \\
(\mathrm{mm} \mathrm{Hg})\end{array}$ & $\begin{array}{l}\text { Result in BP } \\
\text { (average } \\
m m \mathrm{Hg} \text { ) }\end{array}$ \\
\hline Levi et al. ${ }^{5}$ & 41 & Cervical & $\begin{array}{l}\text { Dobutamine }\left(5-15 \mu \mathrm{g} \mathrm{kg}^{-1} \text { per min) and/or dopamine }\right. \\
\left(2-10 \mu \mathrm{gg}^{-1} \text { per } \mathrm{min}\right)\end{array}$ & $\mathrm{MAP}<90$ & $\begin{array}{l}\text { MAP } 110 \text { in } \\
41 \text { patients }\end{array}$ \\
\hline Vale et al. ${ }^{6}$ & 31 & $\begin{array}{l}\text { Cervical, } \\
\text { thoracic }\end{array}$ & $\begin{array}{l}\text { Dopamine }\left(2.5-5 \mu \mathrm{g} \mathrm{kg}^{-1} \text { per } \min \right) \text { followed } \\
\text { by norepinephrine }\left(0.01-0.2 \mu \mathrm{gg}^{-1} \text { per min), if necessary }\right.\end{array}$ & $\mathrm{MAP}<85$ & $\mathrm{MAP}>85$ \\
\hline Billelo et $a l^{41}$ & 16 & Cervical & Dopamine, dobutamine, phenylephrine & $\mathrm{SBP}<90$ & $\mathrm{SBP}>90$ \\
\hline Lehmann et al. ${ }^{1}$ & 11 & $\begin{array}{l}\text { Cervical, } \\
\text { thoracolumbar }\end{array}$ & $\begin{array}{l}\text { Epinephrine, terbutaline, dobutamine, ephedrine, } \\
\text { isoproterenol }\end{array}$ & $\mathrm{SBP}<90$ & $\mathrm{SBP}>90$ \\
\hline Mathias et al. ${ }^{42}$ & 5 & Cervical & Norepinephrine & $\mathrm{MAP}<90$ & MAP 96 \\
\hline
\end{tabular}

Abbreviations: MAP, mean arterial pressure; SBP, systolic blood pressure.

Table 5 Duration of vasopressor support in patients with $\mathrm{SCl}$

\begin{tabular}{|c|c|c|c|}
\hline Study & $\begin{array}{l}\text { No. of } \\
\text { patients }\end{array}$ & Medication & $\begin{array}{l}\text { Duration average } \\
\text { (days) }\end{array}$ \\
\hline Vale et $a l^{6}$ & 31 & $\begin{array}{l}\text { Dopamine }\left(2.5-5 \mu \mathrm{g} \mathrm{kg}^{-1} \text { per min) followed by norepinephrine }\right. \\
\left(0.01-0.2 \mu \mathrm{g} \mathrm{kg}^{-1} \text { per min), if necessary }\right.\end{array}$ & 7 \\
\hline Levi et $a .^{5}$ & 41 & Dobutamine $\left(5-15 \mu \mathrm{g} \mathrm{kg}^{-1}\right.$ per $\left.\min \right)$ and/or dopamine $\left(2-10 \mu \mathrm{g} \mathrm{kg}^{-1}\right.$ per min) & 5.4 \\
\hline Levi et al. $^{40}$ & 103 & - & 5 \\
\hline Wolf et al. ${ }^{30}$ & 47 & - & 5 \\
\hline
\end{tabular}


Table 6 Most commonly used vasoactive agents ${ }^{16,18,23}$

\begin{tabular}{|c|c|c|c|c|}
\hline Agent & $\begin{array}{l}\text { Common } \\
\text { dosage ranges }\end{array}$ & $\alpha$-Receptor & $\beta$-Receptor & Hemodynamic response \\
\hline \multirow[t]{2}{*}{ Dopamine $\left(\mu \mathrm{g} \mathrm{kg}^{-1}\right.$ per $\left.\mathrm{min}\right)$} & $2-10$ & $(-)$ & ++ & Inotropic and chronotropic effect, mild vasodilatory effect \\
\hline & $10-20$ & ++ & ++ & $\begin{array}{l}\text { Peripheral vasoconstriction with preserved chronotropic } \\
\text { and inotropic effects }\end{array}$ \\
\hline Dobutamine $\left(\mu \mathrm{g} \mathrm{kg}^{-1}\right.$ per min) & $5-15$ & $(-)$ & ++ & Inotropic effect with mild vasodilation \\
\hline Epinephrine ( $\mu \mathrm{g} \mathrm{kg}^{-1}$ per min) & $1-10$ & ++ & ++ & Increased cardiac contractility and peripheral vasoconstriction \\
\hline Norepinephrine $\left(\mu \mathrm{g} \mathrm{min}^{-1}\right)$ & $1-20$ & ++ & + & Both increased cardiac contractility and peripheral vasoconstriction \\
\hline Phenylephrine $\left(\mu \mathrm{g} \min ^{-1}\right)$ & $10-100$ & ++ & $(-)$ & Arterial vasoconstriction \\
\hline Vasopressin $\left(\mathrm{U}_{\mathrm{min}^{-1}}\right)$ & $0.01-0.04$ & & & Vasoconstriction \\
\hline Isoproterenol ( $\mu \mathrm{g} \mathrm{kg}^{-1}$ per min) & $0.03-0.15$ & $(-)$ & ++ & Powerful inotropic agent \\
\hline Amiodarone $\left(\mu \mathrm{g} \mathrm{kg}^{-1}\right.$ per $\left.\mathrm{min}\right)$ & $5-10$ & & & Vasodilation \\
\hline Milrinone ( $\mu \mathrm{g} \mathrm{kg}^{-1}$ per $\left.\min \right)$ & $0.3-1.5$ & & & Inotropic agent with vasodilation \\
\hline
\end{tabular}

vasopressor with both inotropic and chronotropic as well as vasoconstrictive properties. Dopamine and norepinephrine have an effect on both $\alpha_{1}$ - and $\beta_{1}$-receptors and are reasonable choices. ${ }^{16,18,23}$ For lower thoracic lesions, a peripheral vasoconstrictor is needed. Phenylephrine specifically regulates peripheral vasodilation by acting only on $\alpha_{1}$ receptors and can be used for lower thoracic and lumbar cord injuries but not for upper thoracic or cervical injuries. ${ }^{16,18,23}$ Dobutamine exerts its effect prominently as an inotropic agent and its use in SCI is limited because of its effect on vasodilation and possible reflex bradycardia. ${ }^{24}$ Epinephrine, even though it is both an $\alpha$-receptor and $\beta$-receptor agonist, may cause arrhythmias and require close monitoring. Vasopressin is not used in the setting of SCI because of its antidiuretic effects leading to water retention and hyponatremia. ${ }^{17}$ It is only used in cases of hypotension refractory to catecholamines. ${ }^{23}$ Isoproterenol, amiodarone and milrinone cannot reverse hypotension in SCI. ${ }^{23}$

In SCIs, the choice of the appropriate vasopressor depends on the patient's hemodynamic profile and the level of the cord injury and usually is an agent containing mainly $\alpha_{1}$ adrenergic activity but also sometimes $\beta_{1}$-adrenergic activity.

Neurogenic shock starts immediately after injury when the spinal sympathetic pathways are disconnected at the site of injury while parasympathetic discharge continues unopposed through the vagal nerve. This may last for several days to 6 weeks until segmental neuronal connections and reflex cycles gradually reappear distal to the level of injury, even without sympathetic discharge return. ${ }^{25}$ At that time, reflex hyperactivity begins manifesting as muscle spasms and elevation of blood pressure. ${ }^{14,26}$ Furthermore, Ko and coworkers $^{27,28}$ specified that the time of return of deep tendon reflexes after SCI is within the first couple of weeks after injury with the delayed plantar reflex being the first followed by the bulbocavernous and cremasteric reflex. However, no established connection between spinal shock and neurogenic shock does exist.

Vale et al. used a minimum duration of 7 days after injury for hemodynamic treatment of symptomatic patients. ${ }^{6,16}$ This duration was determined based on an experimental animal SCI study that showed that between days 3 and 5 after injury, the spinal cord experienced the greatest degree of cord edema and vascular congestion. ${ }^{29}$ Levi et al. ${ }^{5}$ used dobutamine at a mean dose of $5.4 \mu \mathrm{g} \mathrm{kg}^{-1}$ per min for a mean duration of 5.7 days.

Our study found that most clinicians performed vasopressor support for approximately 5-7 days. Longer duration of treatment may interfere with renal function due to the adrenergic effect on the renal arteries.

Mean arterial pressure is determined by arterial catheter placement. It can be determined by the formula $\mathrm{MAP}=\mathrm{DAP}+1 / 3(\mathrm{SBP}-\mathrm{DBP})$, where DAP stands for diastolic blood pressure and SBP for systolic blood pressure. ${ }^{23}$ Maintaining MAP above $85-90 \mathrm{~mm} \mathrm{Hg}$ has been shown to improve the outcome of patients with ASCI. ${ }^{5,13,30}$ MAP should not be elevated above the normal range even in severe cord injuries, as experimental studies have shown. ${ }^{12}$ The goal of treating hypotension in patients with SCI should be to maintain an SBP at or above $85-90 \mathrm{~mm} \mathrm{Hg}$, according to consensus panel of Consortium for Spinal Cord Medicine. $^{7}$

\section{Conclusions}

Given that rectifying systemic hypotension is one of the only clinical interventions that currently appear to influence neurologic outcome after ASCI, it is surprising that so little clinical evidence exists to address the fundamental questions that we posed in this systematic review. This relates to the problems that have plagued the SCI field in evaluating interventions that potentially alter neurologic outcome: the relatively low incidence of ASCI (making patient recruitment into clinical trials difficult), and the strikingly variable extent of spontaneous neurologic recovery among individuals of different ASIA impairment grades (making it necessary to recruit many patients to have sufficient statistical power). ${ }^{31}$ Intensive management of blood pressure appears to be of neurologic benefit, as it is in traumatic brain injury, but addressing the fundamentally important questions such as 'what should the target MAP be set at, for how long and with what drugs?' is obviously challenging. Complicating the matter is the recent report by Kwon et al. ${ }^{32}$ that indicates that intrathecal pressure may increase postoperatively in patients with ASCI (with a concomitant decrease in spinal cord perfusion pressure). This confounds the interpretation of how well the systemic MAP truly reflects cord perfusion, 
and raises the question of whether intrathecal pressure monitoring analogous to that performed in traumatic brain injury is warranted. For now, the recommendations are to avoid hypotension and maintain MAP above $85-90 \mathrm{~mm} \mathrm{Hg}$ for the first 5-7 days after injury with volume expansion and vasopressors as needed. Much more clinical research is necessary in the future to make more refined recommendations for this patient population.

\section{Conflict of interest}

The authors declare no conflict of interest.

\section{Acknowledgements}

We thank Mitchell Maltenfort, Department of Neurological Surgery, Thomas Jefferson University, biostatistician, for statistical analysis and help.

\section{References}

1 Lehmann KG, Lane JG, Piepmeier JM, Batsford WP. Cardiovascular abnormalities accompanying acute spinal cord injury in humans: incidence, time course and severity. I Am Coll Cardiol 1987; 10: 46-52.

2 Piepmeier JM, Lehmann KB, Lane JG. Cardiovascular instability following acute cervical spinal cord trauma. Cent Nerv Syst Trauma 1985; 2 : 153-160.

3 Furlan JC, Fehlings MG. Cardiovascular complications after acute spinal cord injury: pathophysiology, diagnosis, and management. Neurosurg Focus 2008; 25: E13.

4 Chesnut RM, Marshall LF, Klauber MR, Blunt BA, Baldwin N, Eisenberg HM et al. The role of secondary brain injury in determining outcome from severe head injury. J Trauma 1993; 34: 216-222.

5 Levi L, Wolf A, Belzberg H. Hemodynamic parameters in patients with acute cervical cord trauma: description, intervention, and prediction of outcome. Neurosurgery 1993; 33: 1007-1016; discussion 1016-17.

6 Vale FL, Burns J, Jackson AB, Hadley MN. Combined medical and surgical treatment after acute spinal cord injury: results of a prospective pilot study to assess the merits of aggressive medical resuscitation and blood pressure management. J Neurosurg 1997; 87: 239-246.

7 Consortium for Spinal Cord Medicine. Early acute management in adults with spinal cord injury: a clinical practice guideline for health-care professionals. Spinal Cord Med (May) 2008, 1-69.

8 Methods of the systematic reviews. In: Eng JJ Teasell RW, Miller WC, Wolfe DL, Twonson AF, Aubut J, Abramson C, Hsieh JTC, Connoly S (eds). Spinal Cord Rehabilitation Evidence. Vancouver, 2006, pp 2.1-2.12. http://www.icord.org/scire; Accessed 1 November 2009.

9 Clark O, Djulbegovic B. Forest plots in Excel software (data sheet). 2001. http://www.evidencias.com/forest01.xls; Accessed 14 Sep 2009.

10 Bravo G, Guizar-Sahagun G, Ibarra A, Centurion D, Villalon CM. Cardiovascular alterations after spinal cord injury: an overview. Curr Med Chem Cardiovasc Hematol Agents 2004; 2: 133-148.

11 Gondim FA, Lopes Jr AC, Oliveira GR, Rodrigues CL, Leal PR, Santos AA et al. Cardiovascular control after spinal cord injury. Curr Vasc Pharmacol 2004; 2: 71-79.

12 Guha A, Tator CH, Rochon J. Spinal cord blood flow and systemic blood pressure after experimental spinal cord injury in rats. Stroke 1989; 20: 372-377.

13 Tuli S, Tuli J, Coleman WP, Geisler FH, Krassioukov A. Hemodynamic parameters and timing of surgical decompression in acute cervical spinal cord injury. J Spinal Cord Med 2007; 30: 482-490.

14 Raw DA, Beattie JK, Hunter JM. Anaesthesia for spinal surgery in adults. Br J Anaesth 2003; 91: 886-904.

15 Ducker TB, Lucas JT, Wallace CA. Recovery from spinal cord injury. Clin Neurosurg 1983; 30: 495-513.

16 Blood pressure management after acute spinal cord injury. Neurosurgery 2002; 50: S58-S62.

17 Stratman RC, Wiesner AM, Smith KM, Cook AM. Hemodynamic management after spinal cord injury. Orthopedics 2008; 31: 252-255.

18 Nockels RP. Nonoperative management of acute spinal cord injury. Spine 2001; 26: S31-S37.

19 Walleck CA. Neurologic considerations in the critical care phase. Crit Care Nurs Clin North Am 1990; 2: 357-361.

20 Fehlings MG, Tator $\mathrm{CH}$, Linden RD. The relationships among the severity of spinal cord injury, motor and somatosensory evoked potentials and spinal cord blood flow. Electroencephalogr Clin Neurophysiol 1989; 74: 241-259.

21 Fehlings MG, Tator $\mathrm{CH}$, Linden RD. The effect of nimodipine and dextran on axonal function and blood flow following experimental spinal cord injury. J Neurosurg 1989; 71: 403-416.

22 Stevens RD, Bhardwaj A, Kirsch JR, Mirski MA. Critical care and perioperative management in traumatic spinal cord injury. J Neurosurg Anesthesiol 2003; 15: 215-229.

23 Adams Jr AC, Biffl WL, Cioffi WG. Surgical critical care, cardiovascular system. In: Townsend Jr CM (ed). Sabiston Textbook of Surgery. Saunders: Philadelphia, 2007.

24 Ball PA. Critical care of spinal cord injury. Spine 2001; 26: S27-S30.

25 Stjernberg L, Blumberg H, Wallin BG. Sympathetic activity in man after spinal cord injury. Outflow to muscle below the lesion. Brain 1986; 109(Part 4): 695-715.

26 Hambly PR, Martin B. Anaesthesia for chronic spinal cord lesions. Anaesthesia 1998; 53: 273-289.

27 Ko HY, Ditunno Jr JF, Graziani V, Little JW. The pattern of reflex recovery during spinal shock. Spinal Cord 1999; 37: 402-409.

28 Weinstein DE, Ko HY, Graziani V, Ditunno Jr JF. Prognostic significance of the delayed plantar reflex following spinal cord injury. J Spinal Cord Med 1997; 20: 207-211.

29 Yashon D, Bingham Jr WG, Faddoul EM, Hunt WE. Edema of the spinal cord following experimental impact trauma. J Neurosurg 1973; 38: 693-697.

30 Wolf A, Levi L, Mirvis S, Ragheb J, Huhn S, Rigamonti D et al. Operative management of bilateral facet dislocation. J Neurosurg 1991; 75: 883-890.

31 Fawcett JW, Curt A, Steeves JD, Coleman WP, Tuszynski MH, Lammertse D et al. Guidelines for the conduct of clinical trials for spinal cord injury as developed by the ICCP panel: spontaneous recovery after spinal cord injury and statistical power needed for therapeutic clinical trials. Spinal Cord 2007; 45: 190-205.

32 Kwon BK, Curt A, Belanger LM, Bernardo A, Chan D, Markez JA et al. Intrathecal pressure monitoring and cerebrospinal fluid drainage in acute spinal cord injury: a prospective randomized trial. J Neurosurg Spine 2009; 10: 181-193.

33 Wallace $\mathrm{MC}$, Tator $\mathrm{CH}$. Successful improvement of blood pressure, cardiac output, and spinal cord blood flow after experimental spinal cord injury. Neurosurgery 1987; 20: 710-715.

34 Wallace MC, Tator $\mathrm{CH}$. Failure of naloxone to improve spinal cord blood flow and cardiac output after spinal cord injury. Neurosurgery 1986; 18: 428-432.

35 Dolan EJ, Tator $\mathrm{CH}$. The treatment of hypotension due to acute experimental spinal cord compression injury. Surg Neurol 1980; 13: $380-384$.

36 Guha A, Tator $\mathrm{CH}$, Smith $\mathrm{CR}$, Piper I. Improvement in post-traumatic spinal cord blood flow with a combination of a calcium channel blocker and a vasopressor. J Trauma 1989; 29: 1440-1447.

37 Gambardella G, Collufio D, Caruso GN, Abbate F, Germana G, Tomasello F. Experimental incomplete spinal cord injury: treatment with a combination of nimodipine and adrenaline. J Neurosurg Sci 1995; 39: 67-74. 
38 Ross IB, Tator CH. Further studies of nimodipine in experimental spinal cord injury in the rat. J Neurotrauma 1991; 8: 229-238.

39 Dyste GN, Hitchon PW, Girton RA, Chapman M. Effect of hetastarch, mannitol, and phenylephrine on spinal cord blood flow following experimental spinal injury. Neurosurgery 1989; 24: 228-235.

40 Levi L, Wolf A, Rigamonti D, Ragheb J, Mirvis S, Robinson WL. Anterior decompression in cervical spine trauma: does the timing of surgery affect the outcome? Neurosurgery 1991; 29: 216-222.

41 Bilello JF, Davis JW, Cunningham MA, Groom TF, Lemaster D, Sue LP. Cervical spinal cord injury and the need for cardiovascular intervention. Arch Surg 2003; 138: 1127-1129.

42 Mathias CJ, Frankel HL, Christensen NJ, Spalding JM. Enhanced pressor response to noradrenaline in patients with cervical spinal cord transection. Brain 1976; 99: 757-770.

\section{Editorial Note on: A systematic review of the evidence supporting a role for vasopressor support in acute $\mathrm{SCI}$}

Spinal Cord (2010) 48, 362; doi:10.1038/sc.2009.167;

published online 24 November 2009

Editorial Note on: Spinal Cord (2010) 48, 356-362; doi:10.1038/sc.2009.150; published online 24 November 2009

Five thousand years ago, Egyptian physicians described their observations of a subject with spinal cord injury (SCI) and for the first time documented the possible presence of neurogenic shock: '... he has become pale and developed severe weakness...' (Edwin Smith Papyrus; circa 16501550 BC). The review by Ploumis and colleagues published in this issue of Spinal Cord includes a systematic evaluation of the literature and explores our present knowledge and practice of management of low arterial blood pressure (BP) that is commonly observed following SCI as a result of neurogenic shock (arterial BP below $90 \mathrm{~mm} \mathrm{Hg}$ ). ${ }^{1}$

We are now well aware that injury to the spinal cord damages not only motor and sensory pathways but also the descending pathways that are involved in autonomic control. $^{2,3}$ In particular, the loss of descending tonic sympathetic control appears to be a major cause of the cardiovascular instability during the acute post-traumatic stage. 4 Low arterial BP and persistent bradycardia are common features of neurogenic shock that occurs after SCI. The profound hypotension commonly observed following SCI is in itself a life-threatening condition. In addition, hypotension may contribute to ischemia of the already compromised spinal cord, and is thus a possible factor in the cascade of secondary mechanisms that are involved in further damage of fragile neural tissue. ${ }^{5}$

At the present time of significant interest in clinical interventions and various possible treatment strategies following SCI, we have to be aware of possible ramifications of the outcome of unstable $\mathrm{BP}$ in these individuals. A recent analysis of the data from the Sygen trial showed that hemodynamic parameters varied significantly with the severity of cervical SCI, and over time (in the same individuals) during evaluation of patients before randomization. ${ }^{6}$ Although presently we do not have a consensus on management of hemodynamic parameters immediately after SCI, this issue will likely have to be addressed in future investigations and in design of clinical trials.

\section{A Krassioukov \\ Department of Medicine, University of British Columbia, Vancouver, Canada E-mail: Andrei.Krassioukov@vch.ca}

\section{References}

1 Krassioukov AV, Karlsson AK, Wecht JM, Wuermser LA, Mathias CJ, Marino RJ. Assessment of autonomic dysfunction following spinal cord injury: rationale for additions to International Standards for Neurological Assessment. J Rehabil Res Dev 2007; 44: 103-112.

2 Furlan JC, Fehlings MG, Shannon P, Norenberg M, Krassioukov AV. Descending vasomotor pathways in humans: correlation between axonal preservation and cardiovascular dysfunction after spinal cord injury. J Neurotrauma 2003; 20: 1351-1363.

3 Mathias CJ, Frankel HL. In: Mathias CJ, Bannister R (eds). Autonomic Disturbances in Spinal Cord Lesions. Oxford University Press: Oxford, UK, 2002, pp 494-513.

4 Krassioukov AV, Claydon VE. The clinical problems in cardiovascular control following spinal cord injury: an overview. Prog Brain Res 2006; 152: 223-229.

5 Tator CH. Review of experimental spinal cord injury with emphasis on the local and systemic circulatory effects. Neurochirurgie 1991; 37: 291-302.

6 Tuli S, Tuli J, Coleman WP, Geisler FH, Krassioukov AV. Hemodynamic parameters and timing of surgical decompression in acute cervical spinal cord injury. I Spinal Cord Med 2007; 30: 25-33. 